\title{
Survey of the Incidence and Severity of Powdery Mildew and Rust on Pea (Pisum sativum L.) in Sultanpur District of Uttar Pradesh, India
}

\author{
Divya $^{1}{ }^{*}$, Shashi Tiwari ${ }^{1}$, Arun Kumar ${ }^{2}$, J. K. Tiwari ${ }^{3}$ and Akanksha Tiwari ${ }^{4}$ \\ ${ }^{1}$ Division of Plant Pathology, Sam Higginbottom University of Agriculture Technology and \\ Science, Prayagraj (UP), India \\ ${ }^{2}$ Bihar Agriculture University Sabour, Bhagalpur (Bihar), India \\ ${ }^{3}$ National Horticultural Research and Development Foundation, Patna (Bihar), India \\ ${ }^{4}$ Ganpat Sahaai P.G.College, Sultanpur (UP), India \\ *Corresponding author
}

\section{A B S T R A C T}

\begin{tabular}{|l|}
\hline Key w o r d s \\
Airborne disease, \\
Sowing, Yield \\
losses, Yield \\
biomass \\
\hline Article Info \\
\hline Accepted: \\
26 April 2020 \\
Available Online: \\
10 May 2020 \\
\hline
\end{tabular}

Powdery mildew and Rust are major diseases of pea of worldwide distribution. Powdery mildew and Rust is an airborne disease. Powdery mildew is a particularly damaging in late sowing or in late maturity varieties. It is caused by Erysisphe pisi. The disease can cause $20-50 \%$ yield losses, reducing total yield biomass, number of pods per plant, number of seeds per pod, plant height and number of nodes. The disease also affects green pea quality. Pea rust is characterized by the appearance of two types of symptoms. Early symptoms develop on abaxial side of older leaves and form round to oval aecidia. Initially aecidia form creamy white to light yellow to bright orange colored pustules on the leaf and stem. Surveys was conducted in seven blocks and each block cover four villages of Sultanpur district for powdery mildew and rust disease severity. During survey, maximum powdery mildew severity (23.34) was observed in Lambhua, followed by Kurebhar (21.30), Dhanpatganj (21.24), Kurwar (21.19), Dubeypur (20.05), Bhadaiyan (18.74). Powdery mildew disease severity was found to be least in Jaisinghpur (15.95). Similarly, maximum rust severity was observed in Jaisinghpur (49.20) followed by Dhanpatanj (48.69), Dubeypur (43.74), Lambhua (42.07), Kurwar (40.61), Bhadaiyan (37.65). Rust disease severity was found to be least in Kurebhar (30.02).

\section{Introduction}

Pea (Pisum sativum L.) is a cool season legume grown worldwide as a source of protein both for human food and animal feed. It belongs to the family (Fabaceae)
Leguminosae. "Pisum sativum L." sub species "Hortense" originated from common field pea. Due to its very old history of Domestication, versatile use as vegetables, pulses and feed, it is important food legumes in the world (Choudhury et al., 2006). 
India is the largest producer, consumer and importer of pulses in the world. In India pulses are grown about 24-26 million hectares of area producing 17-19 million tones of pulses annually. India accounts for over one third of the total world area and over 20 per cent of total world pulse production. Uttar Pradesh accounts for 70 per cent of the total pea production in India (Indiastat, 2014) .The area under pea in Uttar Pradesh during the year 2014-15, the area was 22.15 thousand hectares with production 228 thousand tones.

Among the various diseases of pea, Powdery mildew caused by Erysiphe pisi and rust caused by Uromyces fabae are two major diseases causing severe loss with in short period of time. In years of epidemics, affected leaves dry up and fall off, and pods remain undeveloped, which consequently results in yield losses of higher than 30\% (EPPO, 2012) - Among the various diseases of pea Powdery mildew, rust are two major diseases causing severe loss with in short period of time. Powdery mildew (Erysiphe pisi) appears in epidemic form when the plants are in the pod stage towards the end of January and in February.

The disease is characterized by the formation of white, floury patches initially on the leaf progressing towards tendrils, pods and stems covering most of the aerial part at advancement of the disease. The losses in yield in a $100 \%$ infected crop were estimated to be $21-31 \%$ in pod number and $26-47 \%$ in pod weight (Munjal et al., 1963). The pathogen causes up to $50 \%$ yield losses and reduces pod quality (Dixon, 1987). Rust (Uromyces fabae) appears as orange-brown pustules with a light green halo on leaves, which can spread to stems (Ali et al., 2000).

When both diseases occur together, there is a severe damage to leaves and pods resulting in heavy loss of yield ranging from 50 to $100 \%$
(Janila et al., 2001). The survey carried out at 28 villages of 7 blocks of Sultanpur district of Uttar Pradesh indicated that pea found to be naturally infected by several leaf infecting fungi including Erysiphe pisi (Saxena and Gupta, 1981) \& Uromyces fabae.

Roving surveys were conducted and the observation on diseases severity, stage of the crop and variety were recorded. Observations on powdery mildew disease were recorded on randomly selected plants from the bottom, middle and top leaves. Disease intensity was recorded on a 0-9 disease rating scale (Mayee and Datar, 1986) and percent disease incidence (PDI) was calculated as per Wheeler (1969).

\section{Materials and Methods}

An intensive survey was conducted to assess the severity of the powdery mildew and rust disease and to collect different isolates of Erysiphe pisi and Uromyces fabae causing powdery mildew and rust in pea in different localities of 28 villages of 7 blocks of sultanpur district of Uttar Pradesh. Disease severity were recorded by random sampling techniques from 5 plants from farmers field on $0-5$ scale suggested by Mayee \& Datar,1986 for rust while 0-9 scale for powdery mildew as suggested by Saari \& Prescott,1975 shown in tables 1 and 2 respectively. Percent disease incidence (PDI) was calculated by using the formula given by Wheeler (1969).

Percent disease index $(\mathrm{PDI})=($ Sum of individual ratings/ No. of plants examined $x$ disease scale) $\times 100$

\section{Results and Discussion}

A roving survey was carried out in Sultanpur district of Uttar Pradesh during January \& February. 
Twenty eight villages of seven blocks of Sultanpur district was surveyed as explained in Material and Methods.

Maximum mean percent disease incidence (PDI) for powdery mildew of pea was observed in lambhua block (23.34) followed by Kurebhar block (21.30), whereas minimum per cent disease incidence was noticed in jaisinghpur block (15.95).

In Dubeypur Block, four villages were surveyed, viz., Ahimana, Amhat, Bahadurpur, Bahrauli. Among them, In Dubeypur block the maximum severity $(24.76 \%)$ was recorded at bahadurpur, followed by Amhat village with a severity of $(21.70 \%)$ whereas, least severity (12.89\%) was recorded in Baharauli.

In Kurwar block, Four villages were surveyed, viz., Kudwar, Parsipur, Sohgdali, Tiraehha. Among them, In Kurwar block the maximum severity $(25.26 \%)$ was recorded in Parsipur followed by Kudwar with the severity of $(23.90 \%)$. The least severity $(15.00 \%)$ of powdery mildew was recorded in Tiraehha village.

In Dhanpatganj block, Four villages were surveyed, viz., Semrauna, Saraiyabharth, Tikar, Majhwar. Among them, In Dhanpatganj block the maximum severity (24.00\%) was recorded in Saraiyabharth followed by Tikar with the severity of (23.60 $\%)$. The least severity $(14.40 \%)$ of powdery mildew was recorded in Semrauna village.

In Lambhua Block, Four villages were surveyed, viz., Jamkhuri, Rajaumri, Arjunpur, Parasrampur. Among them, In Lambhua block the maximum severity $(24.00 \%)$ was recorded at Rajaumri, followed by Arjunpur village with a severity of $(23.89 \%)$ whereas, least severity $(22.45 \%)$ was recorded in Jamkhuri.
In Bhadaiyan block, Four villages were surveyed, viz., Bhadaiyan, Ramgarh, Pakhrauli, Kuchh Muchh. Among them, In Bhadaiyan Block the maximum severity $(21.00 \%)$ was recorded in Bhadaiya followed by Ramgarh with the severity of $(20.99 \%)$. The least severity (15.98\%) of powdery mildew was recorded in Pakhrauli village.

In Jaisinghpur Block, Four villages were surveyed, viz., Barausa, Ugharpur, Athaisi, Belhari. Among them, In Jaisinghpur block the maximum severity (23.00\%) was recorded at Belhari, followed by Ugharpur village with a severity of $(14.78 \%)$ whereas, least severity $(12.00 \%)$ was recorded in Athaisi.

In Kurebhar block,Four villages were surveyed, viz., Katka Khanpur, Purkhipur, Saifullaganj, Phulpur. Among them,in Kurebhar block the maximum severity $(23.32 \%)$ was recorded in Saifullaganj followed by Phulpur with the severity of $(21.12 \%)$. The least severity $(20.00 \%)$ of powdery mildew was recorded in Katka Khanpur village.

Among all blocks, maximum powdery mildew severity was observed in Lambhua (23.34), followed by Kurebhar (21.30), Dhanpatganj (21.24), kurwar (21.19), \& Dubeypur (20.05). Powdery mildew disease incidence was found to be least in jaisinghpur (15.95) followed by Bhadaiyan (18.74). The variation of disease severity of Powdery mildew in various localities is mainly due to cultivation practices like varieties, sowing time, spacing, fertilizer, irrigation, soil type, preparation of land \& use of fungicide etc.

Maximum mean per cent disease incidence (PDI) for rust of pea was observed in Jaisinghpur (49.20) followed by Dhanpatganj (48.69), whereas minimum per cent disease incidence was noticed in Kurebhar (30.02). In Dubeypur block, Four villages were surveyed, 
viz., Ahimana, Amhat, Bahadurpur, Bahrauli. Among them, In Dubeypur block the maximum severity $(61.00 \%)$ was recorded at bahrauli, followed by Amhat village with a severity of $(40.26 \%)$ whereas, least severity (35.00\%) was recorded in Bahadurpur.

In Kurwar block, Four villages were surveyed, viz., Kudwar, Parsipur, Sohgdali, Tiraehha. Among them, In Kurwar block the maximum severity $(61.00 \%)$ was recorded in Tiraehha followed by Sohgdali with the severity of $(43.44 \%)$. The least severity (23.99\%) of Rust was recorded in kudwar village. In Dhanpatganj block, Four villages were surveyed, viz., Semrauna, Saraiyabharth,
Tikar, Majhwar. Among them, In Dhanpatganj block the maximum severity $(62.66 \%)$ was recorded in Semrauna followed by Majhwar with the severity of $(54.00 \%)$. The least severity (34.45\%) of powdery mildew was recorded in Saraiyabharth village.

In Lambhua block, Four villages were surveyed, viz., Jamkhuri, Rajaumri, Arjunpur, Parasrampur. Among them, in Lambhua block the maximum severity (51.22\%) was recorded at Rajaumri, followed by Jamkhuri village with a severity of $(51.05 \%)$ whereas, least severity $(29.76 \%)$ was recorded in Parasrampur (Fig. 1).

Table.1 Disease severity scale for powdery mildew infection (Saari and Prescott, 1975)

\begin{tabular}{|l|l|}
\hline \multicolumn{1}{|c|}{ Scale used/leaf area affected } & \multicolumn{1}{c|}{ Remarks } \\
\hline $\mathbf{0}=\mathbf{0} \%$ & Absolutely free from any pustules of powdery mildew \\
\hline $\mathbf{1}=\mathbf{0 . 1}-\mathbf{5 \%}$ & 2-4 pustules on few leaves \\
\hline $\mathbf{2}=\mathbf{5}-\mathbf{9 . 5 \%}$ & Few pustules on some leaves \\
\hline $\mathbf{3}=\mathbf{1 0}-\mathbf{1 5 \%}$ & Few pustules on many leaves \\
\hline $\mathbf{4}=\mathbf{1 5}-\mathbf{3 0 \%}$ & Many pustules on many leaves \\
\hline $\mathbf{5}=\mathbf{3 0}-\mathbf{5 0 \%}$ & Some pustules coalescing each other \\
\hline $\mathbf{6}=\mathbf{5 5}-\mathbf{7 5 \%}$ & Coalescing pustules almost on whole plant \\
\hline $\mathbf{7}=\mathbf{7 5 . 1}-\mathbf{9 0 \%}$ & Powdery growth on leaves and pods \\
\hline $\mathbf{8}=\mathbf{9 0 . 1}-\mathbf{9 8 \%}$ & $\begin{array}{l}\text { Uniform powdery growth without any conspicuous pustules on } \\
\text { whole plant }\end{array}$ \\
\hline $\mathbf{9}=\mathbf{9 8}-\mathbf{1 0 0 \%}$ & $\begin{array}{l}\text { Whole plant covered with powdery mass giving light greyish } \\
\text { white appearance leading to premature drying of plants }\end{array}$ \\
\hline
\end{tabular}

Table.2 Disease severity scale for rust in pea (Mayee and Datar, 1986)

\begin{tabular}{|c|c|}
\hline Scale used & Remarks \\
\hline $\mathbf{0}$ & Leaf and fruit free from rust infection \\
\hline 1 & 2-4 leaves are infected \\
\hline 2 & 6-20\%leaves are infected \\
\hline 3 & 20-35\%leaves are infected \&small patches on fruits \\
\hline 4 & $40-60 \%$ leaves are infected $\&$ fruits are infected \\
\hline 5 & Above $65 \%$ leaves are infected and fruits are infected \\
\hline
\end{tabular}


Table.3 Survey of Powdery mildew and Rust disease of pea in Sultanpur district of Uttar Pradesh

\begin{tabular}{|c|c|c|c|c|c|c|c|}
\hline Block & Villages & Latitude $\left({ }^{\circ} \mathbf{N}\right)$ & $\begin{array}{l}\text { Longitude } \\
\left({ }^{\circ} \mathbf{E}\right)\end{array}$ & Soil type & Variety & $\begin{array}{l}\text { PDI for } \\
\text { powdery } \\
\text { mildew }\end{array}$ & $\begin{array}{l}\text { PDI for } \\
\text { rust }\end{array}$ \\
\hline \multirow[t]{5}{*}{ Dubeypur } & Ahimana & 26.15 & 82.05 & $\begin{array}{l}\text { Deep loamy } \\
\text { soil }\end{array}$ & Azad pea-3 & 20.85 & 38.70 \\
\hline & Amhat & 26.16 & 82.04 & Loamy soil & Local & 21.70 & 40.26 \\
\hline & Bahadurpur & 26.14 & 82.00 & Loamy soil & G-10 & 24.76 & 35.00 \\
\hline & Bahrauli & 26.16 & 82.00 & Loamy soil & Azad pea-3 & 12.89 & 61.00 \\
\hline & Mean & & & & & 20.05 & 43.74 \\
\hline \multirow[t]{5}{*}{ Kurwar } & Kudwar & 26.12 & 82.01 & Loamy soil & G-10 & 23.90 & 23.99 \\
\hline & Parsipur & 26.11 & 82.00 & Loamy soil & G-10 & 25.26 & 34.00 \\
\hline & Sohgdali & 26.18 & 82.05 & Loamy soil & Local & 20.60 & 43.44 \\
\hline & Tiraehha & 26.20 & 83.00 & Loamy soil & G-10 & 15.00 & 61.00 \\
\hline & Mean & & & & & 21.19 & 40.61 \\
\hline \multirow[t]{5}{*}{ Dhanpatganj } & Semrauna & 26.16 & 82.01 & Loamy soil & Azad pea-3 & 14.40 & 62.66 \\
\hline & Saraiyabharth & 26.15 & 82.04 & Loamy soil & Azad pea-3 & 24.00 & 34.45 \\
\hline & Tikar & 26.14 & 82.05 & Loamy soil & Local & 23.60 & 43.65 \\
\hline & Majhwar & 26.13 & 82.00 & Loamy soil & Local & 22.99 & 54.00 \\
\hline & Mean & & & & & 21.24 & 48.69 \\
\hline \multirow[t]{5}{*}{ Lambhua } & Jamkhuri & 27.09 & 83.00 & Loamy soil & Azad pea-3 & 22.45 & 51.05 \\
\hline & Rajaumri & 26.16 & 83.01 & Loamy soil & Local & 24.00 & 51.22 \\
\hline & Arjunpur & 26.14 & 83.04 & Loamy soil & G-10 & 23.89 & 36.26 \\
\hline & Parasrampur & 26.20 & 82.05 & Loamy soil & Azad pea-3 & 23.00 & 29.76 \\
\hline & Mean & & & & & 23.34 & 42.07 \\
\hline \multirow[t]{5}{*}{ Bhadaiyan } & Bhadaiyan & 26.20 & 82.05 & $\begin{array}{l}\text { Deep Loamy } \\
\text { soil }\end{array}$ & Azad pea-3 & 21.00 & 35.00 \\
\hline & Ramgarh & 26.21 & 82.05 & Loamy soil & G-10 & 20.99 & 36.86 \\
\hline & Pakhrauli & 26.16 & 82.02 & Loamy soil & Local & 15.98 & 43.87 \\
\hline & Kuchh muchh & 26.16 & 82.01 & Loamy soil & Azad pea-3 & 16.98 & 34.88 \\
\hline & Mean & & & & & 18.74 & 37.65 \\
\hline \multirow[t]{5}{*}{ Jaisinghpur } & Barausa & 26.14 & 83.00 & Loamy soil & Local & 14.00 & 54.88 \\
\hline & Ugharpur & 26.13 & 82.01 & Loamy soil & Local & 14.78 & 54.09 \\
\hline & Athaisi & 26.21 & 82.05 & $\begin{array}{l}\text { Deep Loamy } \\
\text { soil }\end{array}$ & Azad pea -3 & 12.00 & 61.09 \\
\hline & Belhari & 26.20 & 82.05 & Loamy soil & Azad pea-3 & 23.00 & 26.76 \\
\hline & Mean & & & & & 15.95 & 49.20 \\
\hline \multirow[t]{5}{*}{ Kurebhar } & $\begin{array}{l}\text { Katka } \\
\text { khanpur }\end{array}$ & 26.13 & 82.03 & Loamy soil & Local & 20.00 & 36.00 \\
\hline & Purkhipur & 26.12 & 82.04 & Loamy soil & G-10 & 20.76 & 25.66 \\
\hline & Saifullaganj & 26.10 & 82.00 & Loamy soil & Azad pea -3 & 23.32 & 34.66 \\
\hline & Phulpur & 27.09 & 82.00 & $\begin{array}{l}\text { Deep Loamy } \\
\text { soil }\end{array}$ & G-10 & 21.12 & 23.77 \\
\hline & Mean & & & & & 21.30 & 30.02 \\
\hline
\end{tabular}

PDI- Per cent Disease Incidence 


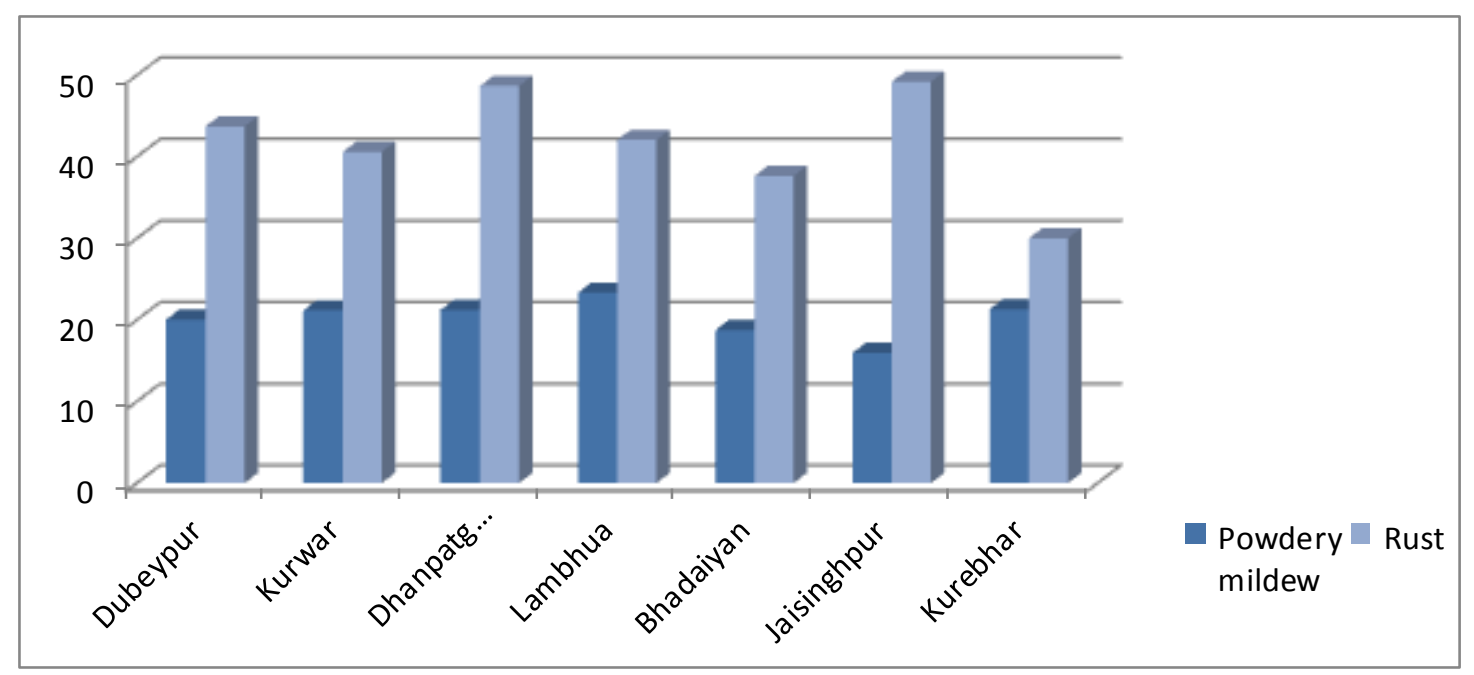

Fig.1

In Bhadaiyan block, Four villages were surveyed, Viz., Bhadaiyan, Ramgarh, Pakhrauli, Kuchh Muchh. Among them, In Bhadaiyan block the maximum severity (43.87\%) was recorded in Pakhrauli followed by Ramgarh with the severity of $(36.86 \%)$. The least severity (34.88\%) of powdery mildew was recorded in Kuchh Muchh village (Table 3).

In Jaisinghpur block, Four villages were surveyed, viz., Barausa, Ugharpur, Athaisi, Belhari. Among them, In Jaisinghpur block the maximum severity (61.09\%) was recorded at Athaisi, followed by Barausa village with a severity of $(54.88 \%)$ whereas, least severity (26.76\%) was recorded in Belhari.

In Kurebhar block,Four villages were surveyed, viz., Katka Khanpur, Purkhipur, Saifullaganj, Phulpur. Among them,In Kurebhar block the maximum severity $(36.00 \%)$ was recorded in Katka khanpur followed by Saifullaganj with the severity of (34.66\%). The least severity $(23.77 \%)$ of powdery mildew was recorded in Phulpur village.

Among all blocks, maximum rust severity was observed in Jaisinghpur (49.20), followed by Dhanpatganj (48.69), Dubeypur (43.74), Lambhua (42.07), Kurwar (40.61), Rust disease incidence was found to be least in Kurebhar (30.02) followed by Bhadaiyan (37.65). The variation of disease severity of Rust in various localities is mainly due to cultivation practices like varieties, sowing time, spacing, fertilizer, irrigation, soil type, preparation of land \&pre use of sulpher etc.

\section{References}

Ali M. Joshi PK. Pandey S. Asokan M. Virmani SM. Kumar R, Kandpal B.K. 2000. Legumes in the Indo-Gangetic Plain of India. (Johansen, C., et. al. Eds.). ICRISAT, Patancheru-502 324, A. P. India and Ithaca, New York, USA: Cornell University. pp. 35-70.

Choudhury, R. P., H. Tanveer and G. P. Dixit (2006). Identification and detection of genetic relatedness among important Varieties of pea (Pisum sativum L.) grown in India. Genetica, 130: 183-191.

Dixon, G. R., 1987. Powdery mildew of vegetables and allied crops. In: D. M. Speaure. (eds), Powdery Mildew. London, UK: Academic Press. 565

EPPO Standards Pea, (2012). http://archives.eppo.org/EPPOStandards 
/PP2_GPP/pp2-14-e.doc

Indiastat. Statistical database. Culled from, 2014.

http://www.indiastat.com/agriculture.

Janila P, Sharma B, Mishra SK. Inheritance of powdery mildew resistance in pea (Pisum sativum L.) Indian Journal of Genetics 2001; 61:129-131.

Mayee CD, Datar VV. Phytopathometry. Technical Bulletin-I, Marathawad Agricultural University, Parbhani, India, 1986, 146.

Munjal, R. L., V. V. Chenulu and T. S. Hora. Assessment of losses due to powdery mildew (Erysiphe polygoni) on pea,
Indian Phytopathology. 19: 260-267, 1963.

Saari E.E, Prescott J.M. 1975. A scale for appraising foliar intensity of wheat diseases. Plant Diseases Reporter 59: 377-380.

Saxena RM, Gupta JS. Field survey for suspected seed transmitted disease of mungbean and urdbean in Uttar Pradesh. Indian Phytopathology 1981; 34(3):340-345.

Wheeler BEJ. An Introduction to Plant Disease. John Wiley Sons Ltd., London, 1969, 301.

\section{How to cite this article:}

Divya, Shashi Tiwari, Arun Kumar, J. K. Tiwari and Akanksha Tiwari. 2020. Survey of the Incidence and Severity of Powdery Mildew \& Rust on Pea (Pisum sativum L.) in Sultanpur District of Uttar Pradesh, India. Int.J.Curr.Microbiol.App.Sci. 9(05): 3148-3154.

doi: https://doi.org/10.20546/ijcmas.2020.905.373 